Imperial Landscapes of Health: Place, Plants, and People between India and Australia, $1800 \mathrm{~s}-1900 \mathrm{~s}$

Author(s): James Beattie

Reviewed work(s):

Source: Health and History, Vol. 14, No. 1, Special Issue: Health and Place: Medicine, Ethnicity, and Colonial Identities (2012), pp. 100-120

Published by: Australian and New Zealand Society of the History of Medicine

Stable URL: $\mathrm{http} / / / \mathrm{www} . j \mathrm{jtor} .0 \mathrm{rg} / \mathrm{stable/10.5401/healthhist.14.1.0100}$

Accessed: 08/01/2013 15:20

Your use of the JSTOR archive indicates your acceptance of the Terms \& Conditions of Use, available at http://www.jstor.org/page/info/about/policies/terms.jsp

JSTOR is a not-for-profit service that helps scholars, researchers, and students discover, use, and build upon a wide range of content in a trusted digital archive. We use information technology and tools to increase productivity and facilitate new forms of scholarship. For more information about JSTOR, please contact support@jstor.org. 


\section{Imperial Landscapes of Health: \\ Place, Plants and People between \\ India and Australia, 1800s-1900s}

\section{James Beattie}

In the nineteenth century, place bore immediately and urgently on questions of imperialism, race, and health. This article considers European strategies to control local environments and improve healthiness through the exchange of people, plants, ideas and garden designs between India and Australia. Migration removed Europeans from unhealthy environments, either permanently (to Australia and elsewhere) or temporarily (to hill stations in India). Trees like the eucalyptus were introduced into India to enhance European health, based on belief they drained sources of disease. I argue a crucial new understanding of the intersection between health and place in the nineteenth-century British Empire can be provided by tracing the networks through which people, plants, and ideas moved to consider the broader imperial frameworks.

\section{Keywords}

Imperial health, acclimatisation, plant transfers, India, Australia, migration, imperialism, climate 


\begin{abstract}
Sing a song of sixpence
Purchased with our lives

Decent English gentlemen,

Roasting with their wives

In the plains of India

Where they die like flies
\end{abstract}

Edith Cuthell, My Garden City on the City of Gardens (1895) ${ }^{1}$

In the nineteenth century, place bore immediately and urgently on questions of imperialism, race, and health. As the excerpt above illustrates, popular belief held that colonisation was paid for with English lives. India's climate increasingly came to be viewed as pathogenic both by Europeans and Indians. This rested on the belief that residence in tropical places displaced Anglo constitutions, and hence bodies and minds. Europeans became fearful of the effects of climatic displacement on their constitutions, which they increasingly saw as unsuited to the heat and humidity of India and its disease regimes. As particular disease and climatic regimes rendered certain Indian groups 'weak and effeminate,' so Europeans believed the same would happen to them. They pointed to the perceived effects of racial degeneration: of tropical climates and diseases dulling the fighting mettle of British soldiers and rendering imperial administrators jabbering wrecks. ${ }^{2}$ Nor were these concerns limited to Europeans. For example, in the late-nineteenth century, Bengali Hindus also feared the degenerating effects of malaria, against which Muslim families were seemingly impervious. $^{3}$

This article considers European strategies to control local environments and thus mitigate the adverse effects of place on mind and body. It demonstrates how concerns about health wove together different Australian and Indian places through the relocation of people, plants, ideas, and garden designs. Migration removed Europeans from India's unhealthy environments, either permanently (to Australia and elsewhere) or temporarily (to hill stations in India). Trees like the eucalyptus were introduced into India to enhance health, based on the belief that they drained sources of disease from the surrounding environment. Ideas of health and garden designs thus underpinned attempts to remake some imperial places in the image of others. I argue that 
considering imperial frameworks to trace the networks through which people, plants, and ideas moved provides crucial new understandings of the intersection between health and place in the nineteenth-century British Empire.

\section{Networks, Ideas, People, and Plants}

Examining the exchanges of people, ideas, and plants between different places in Australia and India adds to the growing work on the importance of networks in understanding imperial institutions and experiences. ${ }^{4}$ Instead of ideas or plants travelling along one-way paths, as was once thought, many historians are now adopting a more decentred and multinodal conceptualisation of Empire, one emphasising transfers between different places that changed over time. ${ }^{5}$ Jodi Frawley, for example, writes of the way in which the meaning of plants shifted from place to place, in terms of both their cultural and scientific descriptions, and their physical attributes. ${ }^{6}$ Both she and Lotte Hughes, among others, stress the complexity of nineteenth-century plant transfers. ${ }^{7}$ With regard to individuals, the scholarship of David Lambert and Alan Lester on 'imperial careering' stresses the importance of colonial experiences in one place shaping individual attitudes and experiences elsewhere in Empire. Their concept, like the model of plant transfers presented by Frawley, Hughes, and others, emphasises the importance of colony-to-colony transfers of ideas and complicates earlier models of ideas being introduced from Europe to the colonies. As applied to this article, the framework of 'imperial careering' demonstrates how health and environmental views from one place were introduced into another. ${ }^{8}$ This study, then, bears out recent research on the complexity of networks by highlighting an under-researched area and pointing to the significance of intra-imperial exchange beyond the so-called major botanical garden hubs of Europe.

What are the advantages of such an approach? Considering the networks through which transfers of people, health ideas, and plants occurred, moves the history of health beyond analyses conducted at a national level or framed by particular disease regimes. While immensely useful, such perspectives can obscure important relationships between certain places. For example, historians have only tended to consider health 
connections within either tropical colonies ${ }^{9}$ or settler colonies. ${ }^{10}$ Rarely have they considered how perceived health problems in one place facilitated exchanges of people, plants or medical ideas among tropical and settler colonies. ${ }^{11}$ In examining such interactions between the Australian colonies and the Indian subcontinent, this article reinforces Warwick Anderson's salient observation that, 'regardless of historiographic trends,' politics and nature 'are continually plotting to reassert the importance of geography, of spatial patterning, in the understanding of disease and health care. ${ }^{12}$

By centring this study on the role of place, it also extends research on medical geography and the connections between environment and health. ${ }^{13}$ First, it considers how perceived health qualities of some plants motivated their introduction. ${ }^{14}$ Second, Indian case-studies extend understandings of the intersections of gardens and colonial health by stressing the importance of health to the creation, perception, and use of gardens as well as the choice of plants in them. ${ }^{15}$ Finally, the article broadens existing studies of Australian health emigration. Most scholarship has focussed on whites moving from Europe to Australia or from the settler colonies, attracted in part by the 'pull' of a perceived better climate as well as lifestyle. ${ }^{16}$ The importance of health in motivating European emigration from India to Australia has also been largely neglected. ${ }^{17}$ When scholars consider Asia, it is to examine ethnic groups from this region, not Europeans. ${ }^{18}$

\section{Migration for Health: Australia and India}

Health and place were significant factors in nineteenth-century migration. Considerations of health influenced migrants' decisions to emigrate, while potential migrant destinations were marketed for their healthful qualities. ${ }^{19}$ Underlying such views were complex medical ideas concerning illness, and the relationship of environment and health. Illness had manifold causes. It might arise as easily from contact with environments as from contact between people. ${ }^{20}$ Sunshine and heat, wind and rain, humidity and cold; one's place and proximity to rotting vegetation: all of these factors-and others-impacted on health. ${ }^{21}$ Miasma was used to express the confused origins of illness and the bewildering role of place, among other 
factors, in the generation of disease. Miasma, a hotly contested concept, retained its popularity in non-medical circles well into the twentieth century. ${ }^{22}$ Until the development of microbial understandings of disease transmission, settlers responded to miasma by closely focusing on a place's qualities. Scent and sight alerted settlers to dangerous areas. Settlers also avoided or attempted to drain low-lying ground like swamps and standing water. ${ }^{23}$

Beyond local places, whole 'tropical' regions - such as India's - came to be pathologised. ${ }^{24}$ Imperialism placed European bodies in unfamiliar situations and subjected them to unknown environmental agents and new diseases, particularly in India. The Indian War of Independence (1857) undermined British confidence that changes in diet and lifestyle could enable them to adapt to India's climate. Even before then, as Mark Harrison has observed, high mortality and morbidity experienced during the First Burma War (1824-26) jolted belief in the ability of British troops (both Indian and European) to serve in Burma. ${ }^{25}$ The bitter and bloody fighting of 1857 thus merely confirmed what many had suspected: that the tropical climate of India was no place for a white man, let alone for a white woman. ${ }^{26}$ Increasing pessimism about the ability of races to acclimatise to regions environmentally different from their own had profound implications for imperial health policy. In the aftermath of the Indian uprising, concern that the weakness of European troops in the Indian climate had encouraged rebellion impressed upon imperial policymakers the vulnerability of British rule to the vagaries of a pathogenic climate. As the British Government formally took control of India from the East India Company (EIC), the House of Commons demanded both an increase in the ratio of British to Indian troops and a reduction in death rates. ${ }^{27}$

The public health of British administrators and military personnel thus became the focus of health investigations and improvements. ${ }^{28}$ Medical topographers led the charge in what became a whole arsenal of health reforms, measuring mortality and morbidity, and examining sanitary measures and disease outbreaks. ${ }^{29}$ Better nutrition, provision of clean drinking water and other sanitary measures, as well as improved barrack design, resulted. Many of these reforms testified spatially to the growing social gulf between Indians and Europeans, with 
cantonments (permanent military camps) now separating Indian and European dwellings. Despite mortality rates among both Indian and British troops correspondingly falling 'significantly, if unevenly, from the early 1880 s, ' ${ }^{30}$ devastating outbreaks of disease (especially cholera and, later, plague) continued to break out in India. ${ }^{31}$ Given both the prevalence of some diseases and European mobility, it is not surprising that long-term residence in India's tropical climate was popularly held to reduce one's lifespan. As a palliative, Europeans who had served in India sought out climates more closely resembling those of Europe, and hence believed to be more suited to their constitutions.

Many British officials and military personnel from India retired to other parts of the Empire, including New Zealand and South Africa. ${ }^{32}$ The latter was a particularly popular resort owing to its dry climate and position as a stopping-off point, pre-Suez Canal, between Britain and India. British officials also sought to return to the United Kingdom. However, as the nineteenth century lengthened, societal opinion turned against the lifestyles of wealthy Anglo-Indians, who were increasingly regarded as corrupt, middle-class upstarts possessing questionable morals and mores. ${ }^{33}$ Medical opinion also cautioned against, as Dr. Copland and Sir James Clark wrote, 'immediate return to a cold climate,' such as Britain's. They stressed it was 'likely to be injurious to persons who have resided in India and suffered from disease produced by the effects of the climate.' 34

Officials in Australia's fledgling colonies, along with those in New Zealand and South Africa, ${ }^{35}$ clamoured to attract wealthy white settlers from India. They commonly sounded a note of alarm by playing on the dangers of India's climate while reassuring migrants of their own colony's salubrity. As Captain James Stirling (1791-1865, the first Governor of Western Australia, 1828-38) explained, India's heat and moisture produced 'unwholesome exhalations,' chiefly malaria. ${ }^{36}$ Malaria struck particular terror into European society in India. It attacked indiscriminately, leaving survivors debilitated and liable to later lapse into fever. Malaria, as another author observed, 'ruins a race, sapping its stamina and destroying its power of work.' Acclimatisation to its effects, he held, was simply impossible. ${ }^{37}$ Cholera was also widely feared, while mental illnesses associated with the tropics were diagnosed as well. ${ }^{38}$

Mindful of such concerns, in 1858 Tasmania's parliament 
established a committee to examine the island's suitability as a military sanatorium. The committee of ten men, including six military officers, recommended Tasmania as a station for aiding in the recovery of white troops from India whose constitutions had been blasted by the sub-continent's disease regime. Anticipating critically high rates of casualties and disablement among troops in British India, as well as difficulties in securing replacements, it suggested the establishment of a two-thousandbed sanatorium. The report strongly noted it would allow:

the disabled Soldier the advantages of the Climate of Tasmania; as, giving him four months in this Colony for the recovery of his health, he could be returned to Calcutta or Bombay in six months after quitting either of those Ports, in all probability quite efficient for duty. ${ }^{39}$

To support claims of its ability to rejuvenate the servants of Empire, the report, following the template of medical topography/ geography then popular across the western world, used newlyrefined statistical techniques to tabulate in exhausting detail information about vegetation, geology, rainfall, seasonal climatic variations, diseases, morbidity and mortality rates, and so on. ${ }^{40}$ The report described the physical appearance of inhabitants, and drew on all manner of information to ascertain the healthiness of particular places on the island. Accordingly, Tasmania's report highlighted the low death rate among troops already stationed there (not quite 8 per 1000 compared to 33 per 1000 in Britain and nearly 50 per 1000 in India). A low death rate, explained the report's compilers, arose due to an absence of temperature extremes on the island.${ }^{41}$ A moderate and evenly distributed rainfall further recommended Tasmania's climate.

In addition to the physical attributes of the island itself, the report presented evidence of Tasmania's beneficence to the human physique. The island was 'free from marsh miasma' while 'neither intermittent nor remittent Fevers occur here. ${ }^{\text {'2 }}$ As the local Member of the Legislative Council, Dr. E. S. P. Bedford, noted, Tasmania's climate had produced 'good effects' among the 'persons coming on sick leave to this Colony from India,' whom he had examined at his medical practice. In addition, he observed, those diseases fatal and prevalent in India were not found in Tasmania. Thus, 
The mild character of the climate; its cool nights; its equal fall of rain during the year; its freedom from malaria; its bright and clear atmosphere; its scenery, and the general English aspect of its Towns, buildings, and cultivations, all have great influence upon persons seeking health after a residence in a warm climate. $^{43}$

Several other Australian proposals for military sanatoria followed in the wake of the formal British takeover of India. ${ }^{44}$ In 1859, Sir James Stirling (1791-1865), the first Governor of struggling Western Australia, published a pamphlet promoting his colony's atmosphere. ${ }^{45}$ Western Australia, he enthused, possessed 'a sea-climate, fresh and invigorating; temperate in point of heat; equable in point of temperature; free from sudden chills.' The hottest season was also the one of the 'greatest draught.' Later, Sir Frederick Napier Broome (1842-96) wrote to the Viceroy of India suggesting that British troops be sent from India to enjoy Western Australia's 'kindly climate.' ${ }^{46}$

Advantageous provisions in settlement schemes also targeted migrants. For example, Tasmania's Immigration Act (1867) granted immigrants from India thirty acres of land, in addition to other benefits to their families. This was only one of several such schemes at the time. ${ }^{47}$ Many ex-Indian military and officials came to Australia in search of health, especially, it seems, between the $1800 \mathrm{~s}$ and the $1870 \mathrm{~s} .{ }^{48}$ While belief in Australia's healthfulness played a major part in these migrations, Australian-Indian shipping connections underpinned them. ${ }^{49}$ Ex-Indian officials and migrants bought estates in colonial Sydney; as did lower ranks. ${ }^{50}$ The regular movement of imperial troops from one area to another also acquainted soldiers with the health advantages of particular places and placed them in a position that made migration easier. ${ }^{51}$ Health anxieties, then, impelled Europeans from India to seek out the perceived healthy climate of southern Australia, something eagerly encouraged by colonial promoters through literature and in legislation.

\section{Hill Stations and Gum Trees}

For those unable to travel to salubrious climates, such as those of the Australian colonies, India's mountain ranges offered them temporary relief. Dotted along India's ranges, the cool 
climates of hill stations provided refuge from the maddening and debilitating heat of the plains. ${ }^{52}$ Belief that their health qualities could be further improved connected Australia and India in other ways through the introduction of eucalyptus, a genus of the Myrtaceae family. It was held to possess important qualities able to improve the health of a locality through its ability to drain swampy land and remove miasma.

Eucalyptus assumed great importance because of the significance of hill stations to India's rule and the need to maintain the healthiness of such places and thus the security of British control. Initially often acquired for defensive needs, by the end of the nineteenth century hill stations had become crucial to India's rule as administrative and military hubs at certain times of year. ${ }^{53}$ In the three hottest months, the Bengal Government officiated from Darjeeling. The Madras Government spent six months in Ootacamund, (now Udhagamandalam), or 'Ooty' as it was affectionately called by climate-blasted officials. From 1884, the permanent military headquarters of the Madras Army joined its Government in Ooctacamund while the Imperial Government travelled over two thousand kilometres from Calcutta to rule from Simla (now Shimla). ${ }^{54}$ All told, tens of thousands of Europeans, their Indian staff, retainers, and others, responded to seasonal fluctuations in climate and disease by moving semi-permanently to India's higher altitudes in search of healthy places.

Some scoffed at the cost of seasonal removal. Others, however, accepted its strategic necessity. Inveterate imperial traveller and commentator, Charles Dilke (1843-1911), recognised that it was impossible to think in such a 'singularly hot, unhealthy, and out of the way' city as Calcutta. Calcutta's harsh climate made Simla's kindlier climate, Dilke wrote, central to "the retention of our Indian empire. ${ }^{55}$ A key component of the perceived healthiness of hill stations rested on their resemblance to other healthy places. Most obviously, Britons identified the temperate-like climates of hill stations as similar to European mountain spas and resorts, places long visited by wealthy British as part of the Grand Tour. The mountain scenery around hill stations also correlated to picturesque traditions of landscape, helping to frame the unfamiliar in familiar artistic conventions. ${ }^{56}$

Journeying to the hill station of Murree, on the foothills of 
the Western Himalayas, Elizabeth Muter fancied herself 'again in an English dell, with the trickling water rolling over the mossy stones. ${ }^{57}$ After 'the interminable flat' of the plain 'with its endless crops and villages,' she expressed 'indescribable relief' at seeing 'the vast mountain, and their [sic] wild and tangled vegetation. ${ }^{58}$ In addition to appearance, hill stations enabled Europeans to engage in physical work and manly sports. These activities, central to constructions of masculinity, were hindered by the debilitating heat of the plains and the sweating jungles of the coast. ${ }^{59}$ Hill stations also reinforced the connections between health, beauty, and productivity. Many of the high country areas near hill stations supported the growth of familiar European plants, as well as the development of commercially valuable plantations such as those of tea, coffee, and opium. ${ }^{60}$ Finally, hill stations may also have restored the badly shaken European belief in the healthiness of rural places over urban ones. India confounded European experiences of health because of its almost equally high death rates in both rural and urban areas, owing particularly to cholera and plague. ${ }^{61}$

While acknowledging the relative healthiness of hill stations, Europeans accepted that even hill stations' local conditions could deteriorate and thus endanger health. Subtle readings of the healthiness of particular places - the plants growing there, the people living there, and the particular climate and soilsguided improvements. One obsever noted the civil station of 'Mysore, Chickmagoor, from its elevation and situation, enjoys the most temperate climate; yet it has the worst reputation for fever' because it stands 'in the midst of paddy flats. ${ }^{62}$ Drainage and tree-planting offered means of enhancing a locality's salubrity, as did plants growing in and around gardens. However, caution was required. Some trees appeared to remove miasma and help drain swampy land. Others, like rotting vegetation and dense, tangled jungle or young or old plants, could generate miasma. ${ }^{63}$ Garden making and planting therefore assumed great importance in health improvements.

Garden making in India reflected a number of imperial sentiments: the civilisation of the wilds, the domestication of foreign places, and British ideas of class, race, gender, and science. Gardens fulfilled multiple functions. For example, as centres of acclimatisation and scientific investigation, botanical gardens were instrumental in helping to commodify and remake 
Indian nature. ${ }^{64}$ But they were also important recreational sites in which officers and their wives could safely perambulate, free from the maddening crowds and lower ranks. Further, many of the trees growing in them had perceived health benefits. ${ }^{65}$ These might derive from qualities of their bark (as in the case of cinchona genus, the C. calisaya, a valued remedy for malaria), or more generally, from their perceived ability to drain land and suck up atmospheric impurities. ${ }^{66}$

Of all the trees introduced into India perhaps the eucalyptus created the greatest hope of putting healthiness into place. Although introduced as early as the 1790 s by Tipu Sultan $(1750-90),{ }^{67}$ it was only really in the nineteenth century that its introduction took place on a large scale across India. Primarily brought to India to meet the rapidly rising fuelwood demands near hill stations, great hopes were also attached to its healthgiving properties. ${ }^{68}$ As a correspondent of the Indian Forester pithily enthused, eucalypts would 'improve the health and to add to the wealth of the country. ${ }^{69}$ Among several enthusiastic promoters of the eucalyptus were Victoria's German-born scientist, Ferdinand von Mueller (1825-96) — 'Baron Blue Gum' to his supporters - and his friend, Richard Schomburgk. Their pronouncements on the qualities of the eucalyptus received enthusiastic praise in the Indian Forester, the key professional organ of Indian forestry. ${ }^{70}$ In India, initial attention focused on the blue gum (Eucalyptus globulus) which forester J. L. Laird praised for its 'utility in hygiene.' Not only absorbing moisture from the atmosphere, its healthful emanations, he noted, possibly neutralised or even destroyed the deadly but unseen miasmas. ${ }^{71}$ Although commenting on the 'exaggeration' of some of its claimed health benefits, as a drainer of miasmic marshes, forestry writer J. E. O'Connor explained, the eucalyptus genus was second to none, 'absorbing daily ten times its own weight of water from the soil. ${ }^{72}$ Translated (French) works such as J. M. Laird's enthusiastic plug for the health-giving properties of Eucalyptus globulus also appeared. ${ }^{73}$

Medical doctors and foresters-many of whom were also medically trained-advanced tree-planting for health in seemingly climatically appropriate areas. ${ }^{74}$ Private and public figures from Australia living in India also experimented with the introduction of Australian species. ${ }^{75}$ For example, the Governor of Madras Presidency, Sir William Thomas Denison (1804- 
71), a former Governor-General of the Australian Colonies, enthusiastically plugged the species' health-giving properties. ${ }^{76}$ Among other sources, Indian officials received seeds from the Royal Botanic Garden Sydney and Melbourne sources. ${ }^{77}$ The roles of officials and private individuals from Australia in the promotion of eucalyptus in India point to the ways in which 'imperial careering' furthered biological transfers. It also highlights the need to examine the role of private planters, not just state institutions, in the making of health landscapes. Such connections demonstrate that health concerns in one place stimulated the exchange of information and seeds not simply between parts of Australia and India, but also, as in the example of Laird, between France and India. ${ }^{78}$

By the 1850s, almost ten-thousand Australian trees were growing near Ootacamund, many having been planted by officials and military personnel. ${ }^{79}$ Surveying the South Indian uplands in 1882, Dietrich Brandis (1824-1907), India's first Inspector General of Forests, commented that their planting has 'altered the appearance of the country.' '[L]arge trees, chiefly Eucalyptus globulus, Acacia melanoxylon and Acacia dealbata,' he recorded, surround the hill stations of Wellington, Ootacamund, and Coonoor (all in the Nilgiris). ${ }^{80}$ In 1883, Ootacamund was 'almost surrounded by a forest of these trees,' while on the Nilgiris eucalypts grew four times as fast as teak. ${ }^{81}$ Plantations of Australian species also provided fuel for Wellington barracks. ${ }^{82}$ In 1873, some sixteen-thousand various eucalypts were growing in Ranikhet (Uttarakhand). ${ }^{83}$ The eucalyptus introduced into India, however, did not grow in the places where it was most wanted - the malarial lowlands. In the 1870s, for example, Madras' Sanitary Commissioner unsuccessfully attempted to introduce eucalypts. ${ }^{84}$ Repeated failures established the climatic limitation of its growth to the hill stations of southern India, reinforcing also the influence of place on attempts at creating healthy landscapes. Places beyond southern India proved to be either too dry or too humid to permit the successful growth of eucalyptus. It was not until the 1920s that research revealed that most eucalyptus introduced into India came from Australia's temperate south, not its north. Thereafter, especially from the 1960s, more ecologically appropriate species were planted, along with the creation of new hybrids. ${ }^{85}$ 


\section{Interchangeable Imperial Places}

As Australian species were introduced into India to promote the healthful qualities of places, so officials in southern Australian drew from Indian experiences to put healthiness into place. While white southern Australians presented their climate as 'health-giving,' lingering fears about places encountered at particular times of the year persisted. Swamps elicited fear, justifying reclamation on the grounds of health and as means of bringing new land into production. Urbanisation also created concerns about the spread of disease. But these were akin to contemporary European health anxieties about similar kinds of places like those of the Lincolnshire and Norfolk Fens in England or Ootacamund and Wellington hill stations in India. What differed were fears of Australia's heat, especially its scorching, desiccating winds blowing from the inland. Through drainage and cultivation, European settlers in Australia engaged in environmental modifications of particular places deemed unhealthy, as Warwick Anderson has noted. Many colonists believed these processes contributed to improvements in the salubrity of local climates. Settlers also recognised the need to don clothing appropriate to the atmosphere of particular places, and to stay indoors on hot and windy days. ${ }^{86}$ Yet, even if one sought refuge indoors, many still complained of the heat.

In the 1840s, Louisa Anne Meredith (1812-95) wrote of Bathurst's 'oven-like atmosphere, the temperature of which is frequently increased tenfold by a "hot wind," when it seems as if a fiery blast from a huge furnace pervaded all space around, rushing into the house through every opening with the force of a hurricane. ${ }^{187}$ In 1854, Sir John Cracroft Wilson spent a few days in Melbourne at the height of summer. 'I never suffered in India,' he complained in his journal, 'so much as I suffered from the persecution of the mosquito wretches,' discomfort worsened by Melbourne's 'excessive' heat ${ }^{88}$ On the Victorian gold fields Europeans, William Howitt (1792-1879) declared in 1855 , laboured 'under an almost Indian sun,' suffering 'the most frightful effects of cramps and rheumatism, of fever and dysentery. ${ }^{89}$

The solution to the dangers of seasonal heat and the unhealthiness of cities was to develop hill stations. Although inspired by Indian models, Australia's retreats came to differ 
from those on the sub-continent in several ways. As Andrea Inglis' fascinating research demonstrates, Australia's hill stations did not replicate the rigid class divisions and military hierarchies of India. Nor did they develop as attempts to flee an alien environment. Instead, she notes, through their incorporation of particular aspects of Australian nature and scenery, they facilitated greater appreciation of Australian environments. By the late-nineteenth century, she shows, they contributed to Australian nationalism by promoting appreciation of the 'native' nature around mountain resorts. Inglis also demonstrates their seasonal nature. For example, the Blue Mountains, west of Sydney, catered to upper- and middleclass needs, combining relaxing walks with cooler summer temperatures, and provided luxury accommodation amidst pleasingly picturesque scenery. Places fulfilling similar needs sprang up in other parts of Australia. South Australians had the summer balm of the Adelaide Hills; Queenslanders could flee to Toowomba. ${ }^{90}$

Just as hill stations in India had eucalyptus, so several of Australia's hill stations introduced perceived health-giving plants from India. Furthermore, they constructed buildings modelled on those of India's hill stations, themselves derivative of English styles. In Victoria in 1884, its Governor (1884-89), Henry Loch (1827-1900), rented the Mt. Macedon property, Rosenheim, as a summer retreat. Its function was commented on by the pastoralist and gold commissioner, Thomas Alexander Browne (better known as the novelist Rolf Boldrewood [1826-1915]), who aptly described Macedon as 'the Simla of Victoria.' ${ }^{91}$ Macedon's 'deodars, Himalayan spruce, Assam tea, Rhododendron Dalhousie, and Indian ducks on the State Nursery Lake,' notes garden historian Paul Fox, 'had been recreated in the image of an Indian hill station.' The mock-Tudor construction of the new two-storied Governor's residence in Macedon closely resembled the Commander-in-Chief's recentlyconstructed abode in Simla (India), further enhancing that image. ${ }^{92}$ These complicated borrowings involved assemblages of different plant and building styles, but with local variations, much as how, for example, the Bengal bungalow developed in form and function over time, when adapted to suit different places and architectural needs. ${ }^{93}$ This evidence suggests the creation of imperial landscapes of health. Visiting Darjeeling 
in 1890, Indianophile, irrigator, and politician Alfred Deakin (1856-1919) noted in his diary: 'cleared patches of garden and dry grass like Macedon - gardens on steep slopes and crests of hills,' seemingly genuinely unaware that the model was India and not the other way round. ${ }^{94}$

The intertwining of ecologies, buildings, and landscapes suggested both by descriptions of Mt. Macedon and of its resemblance to Darjeeling, illustrates the complex historical conjunctions, the complex assemblages of people, places, and plants, that imperialism could throw together. Such a perspective can complicate arguments of national exceptionalism such as that put forward by Andrea Inglis. For Inglis, the perceived health benefits of eucalyptus trees 'gave rise to an original and uniquely Australian form of therapy,' which 'distinguished the Australian hill stations from their British and Asian antecedents. ${ }^{95}$ Yet, as explored in this article, eucalyptus trees were also a ubiquitous presence on many southern Indian hill stations and were highly valued for their health qualities. A panimperial perspective demonstrates that it makes little sense to talk of a 'uniquely Australian form of therapy' because these landscapes of health were instead amalgams of the qualities of different places. 'Around Ootacamund,' as historians Charles and Caroline Carlton note, 'the British created a landscape that has been described as a curious blend of Surrey and Southern Australia, the latter influence being mainly due to the importation of eucalyptus trees. ${ }^{96}$

\section{Conclusion}

In the environmentally attuned nineteenth century, people, places, and plants formed a powerful triumvirate of health. Changes in one, it was thought, forced alterations in the others. This article has argued that maintaining such a balance assumed overriding importance in considerations of one's health, particularly in tropical climates whose disease regimes seemed wholly inimical to European constitutions, and whose qualities spelled the difference between life and death. Fired by such imperial health anxieties, people migrated, transferred plants, and remade places. Underlying such energetic movement was acknowledgement of humanity's ability to shape, yet also be shaped by, environmental influences. Europeans believed in their 
capability to alter localities, such as through the introduction of eucalyptus to Indian hill stations or the acclimatisation of Indian species into Australia. But they also acknowledged their powerlessness against wider influences beyond their control, influences like India's climatic and disease regimes or the seasonal heat of Australia's searing summer plains, both of which led to the establishment of hill stations. Such anxiety and confidence, such enthusiastic movement of people and plants, stimulated the creation of pan-imperial landscapes of health. Studying these relocations of plants and people, examining the remaking of places in Empire, can significantly enrich studies of colonial health.

\section{University of Waikato, New Zealand}

\section{Acknowledgements}

I thank, especially, Ondine Godtschalk, Emily O'Gorman, Cathy Coleborne and Angela McCarthy, as well as the two anonymous referees, for providing helpful critique on drafts of this paper, and Cathy for the invitation to present at the symposium from which this paper is drawn. Finally, I thank Nicola Lemberg for updating endnotes.

1. Edith Cuthell, My Garden City on the City of Gardens (1895), 251, cited in Charles Carlton and Caroline Carlton, The Significance of Gardening in British India (New York: Edwin Mellen Press, 2004), 23.

2. In contrast to Mark Harrison, David Arnold dates the development of this fear to the eighteenth century: David Arnold, "Introduction: Tropical Medicine Before Manson," in Warm Climates and Western Medicine: The Emergence of Tropical Medicine, 1500-1900, edited by David Arnold (Amsterdam: Rodopi, 1996), 1-19. As Arnold notes, Europeans came to view all of India as tropically dangerous. Over time, as germ theory heightened anxieties of Indians as reservoirs of disease, they pathologised people living in tropical climates: David Arnold, Colonizing the Body: State Medicine and Epidemic Disease in Nineteenth-Century India (Berkeley: University of California Press, 1993); Donald Denoon, "Temperate Medicine and Settler Capitalism," in Disease, Medicine and Empire: Perspectives on Western Medicine and the Experience of European Expansion, edited by Roy MacLeod and Milton Lewis (London: Routledge, 1988), 121-38.

3. David Arnold, “'An Ancient Race Outworn:' Malaria and Race in Colonial India, 1860-1930," in Race, Science and Medicine, 1700-1900, edited by Waltraud Ernst and Bernard Harris (London: Routledge, 1999), 123-143.

4. Thomas R. Metcalf, Imperial Connections: India in the Indian Ocean Arena, 1860-1920 (Berkeley: University of California Press, 2007); James Beattie, Empire and Environmental Anxiety: Health, Science, Art and Conservation in South Asia and Australasia, 1800-1920 (Basingstoke: Palgrave Macmillan, 2011); Tony Ballantyne, Orientalism and Race: Aryanism in the British Empire (London: Palgrave Macmillan, 2001); James Beattie, "Recent Directions in the Environmental Historiography of the 


\section{JAMES BEATTIE}

British Empire," History Compass 10, no. 2 (2012): 129-139.

5. Eric Pawson, "Plants, Mobilities and Landscapes: Environmental Histories of Botanical Exchange," Geography Compass 2 (2008): 1464-1477.

6. Jodi Frawley, "Making Mangoes Move," Transforming Cultures eJournal 3, no. 1 (2008), 165-184, http://epress.lib.uts.edu.au/journals/TfC (accessed 13 January 2012).

7. William Beinart and Karen Middleton, "Plant Transfers in Historical Perspective: A Review Article," Environment and History 10 ( 2004): 3-29.

8. David Lambert and Alan Lester, "Imperial Spaces, Imperial Subjects," in Colonial Lives Across the British Empire: Imperial Careering in the Long Nineteenth Century, edited by Alan Lambert and David Lester (Cambridge: Cambridge University Press, 2006), 2.

9. Mark Harrison, "'The Tender Frame of Man': Disease, Climate, and Racial Difference in India and the West Indies, 1760-1860," Bulletin of the History of Medicine 70, no. 1 (1996): 68-93; Arnold, Warm Climates and Western Medicine.

10. Denoon, 121-38.

11. Exceptions are: David Walker, Anxious Nation: Australia and the Rise of Asia 1850-1939 (Brisbane: University of Queensland Press, 1999); David Walker, "The Curse of the Tropics," in A Change in the Weather: Climate and Culture in Australia, edited by Tim Sherratt, Tom Griffiths, and Libby Robin (Canberra: National Museum of Australia Press, 2005), 92-101; Gregory Watters, “The White Doctors' Burden: The Australian Medical Profession and Asia" (PhD thesis, Deakin University, 2011). As are: Morag Bell, “'The Pestilence That Walketh in Darkness': Imperial Health, Gender and Images of South Africa, c. 1880-1910," Transactions of the Institute of British Geographers, New Series 18, no. 3 (1993): 327-41; James Beattie, "Tropical Asia and Temperate New Zealand: Health and Conservation Connections, 1840-1920," in Asia in the Making of New Zealand, edited by Brian Moloughney and Henry Johnson (Auckland: Auckland University Press, 2007), 36-57.

12. Warwick Anderson, "Postcolonial Histories of Medicine," in Locating Medical History: The Stories and their Meanings, edited by Frank Huisman and John Harley Warner (Baltimore: Johns Hopkins University Press, 2004), 287.

13. "Special Issue: Landscapes of Exposure: Knowledge and Illness in Modern Environments," Osiris, $2^{\text {nd }}$ series, 19, (2004), 1-298; Nicholaas A. Rupke, ed., Medical Geography in Historical Perspective (London: Wellcome Trust Centre for the History of Medicine at UCL, 2000); Linda Nash, Inescapable Ecologies: A History of Environment, Disease and Knowledge (Berkeley: University of California Press, 2006); Kaushik Roy, "Managing the Environment: Disease, Sanitation and the Army in BritishIndia, 1859-1913," in Situating Environmental History, edited by Ranjan Chakrabarti (New Delhi: Manohar, 2007), 187-219; Deepak Kumar, ed., Disease and Medicine in India: A Historical Overview (New Delhi: Tulika Books, 2001), 144-65; Elizabeth Whitcombe, "The Environmental Costs of Irrigation in British India: Waterlogging, Salinity and Malaria," in Nature, Culture, Imperialism: Essays on the Environmental History of South Asia, edited by David Arnold and Ramachandra Guha (Delhi: Oxford University Press, 1996), 237-59.

14. On the eucalyptus, note: Ian Tyrrell, True Gardens of the Gods: CalifornianAustralian Environmental Reform, 1860-1930 (Los Angeles: University of California Press, 1999); Brett M. Bennett, "The El Dorado of Forestry: The Eucalyptus in India, South Africa, and Thailand, 1850-2000," International Review of Social History 55 (2010): 27-50. On other medicinal plants, see: Kavita Philip, Civilising Natures: Race, Resources and Modernity in Colonial South India (New Delhi: Orient Longman, 2005).

15. Michael Mann and Samiksha Sehrawat, "A City with a View: The Afforestation of the Delhi Ridge, 1883-1913," Modern Asian Studies 43, no. 2 (2009): 543-70; James Beattie, "Colonial Geographies of Settlement: Vegetation, Towns, Disease and WellBeing in Aotearoa/New Zealand, 1830s-1930s," Environment and History 14, no. 4 (2008): 583-610.

16. See, for example: J. M. Powell, "Medical Promotion and the Consumptive 
Immigrant to Australia," Geographical Review 63, no. 4 (1973): 449-76; Stefan Petrow, Sanatorium of the South? Public Health and Politics in Hobart and Launceston, 18751914 (Hobart: Tasmanian Historical Research Association, 1995).

17. For exceptions note: Diana Dyason, "The Medical Profession in Colonial Victoria, 1834-1901," in MacLeod and Lewis, 194-216; Anderson, "Postcolonial Histories of Medicine," 285-306.

18. Walker, Anxious Nation; Alison Bashford, Imperial Hygiene: A Critical History of Colonialism, Nationalism and Public Health (Houndsmills: Palgrave Macmillan, 2004).

19. Powell; Petrow.

20. Margaret Pelling, "Contagion/Germ Theory/Specificity," in Companion Encyclopedia of the History of Medicine Vol. 1, edited by W. F. Bynum and Roy Porter (London: Routledge, 1993), 309-34.

21. Note: Conevery Bolton Valencius, "Histories of Medical Geography," in Rupke, 3-28.

22. Caroline Hannaway, "Environment and Miasmata," in Bynum and Porter, 292308.

23. Linda Nash, "Finishing Nature: Harmonizing Bodies and Environments in Late-Nineteenth Century California," Environmental History 8, no. 1 (2003): 25-52; Mary Dobson, “"Marsh Fever'-the Geography of Malaria in England," Journal of Historical Geography 6, no. 4 (1980): 357-89; Alain Corbin, Le Miasme et la Jonquille: L'Odorat et l'Imaginaire Social XVIIIe-XIXe Siècles (Manchecourt: Maury Eurolivres, 2000, [1986]); Conevery Bolton Valencius, The Health of the Country: How American Settlers Understood Themselves and their Land (New York: Basic Books, 2002).

24. David Arnold, The Tropics and the Travelling Gaze.

25. Mark Harrison, Climates and Constitutions: Health, Race, Environment and British Imperialism in India, 1600-1850 (New Delhi: Oxford University Press, 1999), 11-8.

26. Alison Bashford, "Medicine, Gender, and Empire," in Gender and Empire, edited by Philippa Levine (New York: Oxford University Press, 2004), 77-111.

27. Hansard, 14 July 1863, Vol. 172, c 776; Radhika Ramasubban, "Imperial Health in British India, 1857-1900," in MacLeod and Lewis, 38-40.

28. Instead it was left to Indians and the private sector to introduce sanitary measures to improve the health of the Indian population. Note: Projit Bihari Mukharji, Nationalizing the Body: The Medical Market, Print and Daktari Medicine (New York: Anthem Press, 2009); Projit Bihari Mukharji, "Structuring Plurality: Locality, Caste, Class and Ethnicity in Nineteenth-Century Bengali Dispensaries," Health and History 9, no. 1 (2007): 80-105.

29. Mark Harrison, Public Health in British India: Anglo-Indian Preventive Medicine, 1859-1914 (Cambridge: Cambridge University Press, 1994); Arnold, Tropics and the Travelling Gaze; David Arnold, Science, Technology and Medicine in Colonial India (Cambridge: Cambridge University Press, 2000), 76-81.

30. Harrison, Public Health, 97.

31. Note: Dhrub Singh, "'Clouds of Cholera': and Clouds Around Cholera, 181770," in Kumar, 144-65; Ian Catanach, "Plague and the Tensions of Empire: India, 1896-1918," in Imperial Medicine and Indigenous Societies, edited by David Arnold (Manchester: Manchester University Press, 1988), 149-71.

32. Beattie, Empire and Environmental Anxiety; Bell.

33. Maya Jasanoff, Edge of Empire: Lives, Culture, and Conquest in the East, 17501850 (New York: Knopf/Fourth Estate, 2005).

34. Military Sanatarium [sic]: Report of the Board of Commissioners, 7 September 1858 (Tasmania: no publisher, 1858), in Tasmania: Miscellaneous 1857-1897, National War Memorial Museum of Australia, Canberra, V354.946008 T 741, 5.

35. Bell, 327-41; Beattie, "Tropical Asia and Temperate New Zealand," 36-57.

36. J. Stirling, Observations on the Climate and Geographical Position of Western Australia, and on its Adaptation to the Purposes of a Sanatorium for the Indian Army in 


\section{JAMES BEATTIE}

a Letter Addressed to J. R. Martin, Esq. (London: J. C. Bridgewater, 1859), 3.

37. "Malaria and the Value of the Eucalyptus," Indian Forester 7, no. 4 (1882): 337.

See also: David Arnold, “"An Ancient Race Outworn': Malaria and Race in Colonial India 1860-1930," in Ernst and Harris, 123-143.

38. Arnold, Science, Technology and Medicine.

39. Military Sanatarium, 3.

40. Valencius, "Histories of Medical Geography," 3-28.

41. Military Sanatarium, 5.

42. Ibid.

43. Bedford, quoted in Military Sanatarium, 12.

44. For an overview, see: Beattie, Empire and Environmental Anxiety, 44-5, 56-60.

45. Stirling.

46. F. Napier Broome to Viceroy of India, Government House, Perth, 11 December, 1885, Despatches on the Subject of a Sanitarium [sic] in Western Australia for the British Troops Serving in India, no. 22, presented to the Legislative Council by His Excellency's Command (Perth: Government Printer, 1886), 4.

47. Andrea Scott Inglis, Summer in the Hills: The Nineteenth-Century Mountain Resort in Australia (Melbourne: Australian Scholarly Publishing, 2007), 56-7.

48. On Western Australia, see: H. Compton to Secretary of State for India, 5 June 1883, Adelaide, British Library, India Office, IOR/L/PJ/6/102/ 1176; Beverley Kingston, "The Taste of India," Australian Cultural History 9 (1990): 36-48; Inglis, 45-64.

49. In the early-nineteenth century, escaped convicts even landed up in Calcutta. Note, for example: "Robert De Bruce Keith Stewart, who had escaped from Botany Bay, provided with a Passage to Port Nicholson," IOR/F/4/299/6923, British Library; Kingston, 39. The East India Company Bengal Army also attempted to recruit in New South Wales.

50. James Broadbent, Suzanne Rickard, and Margaret Steven, India, China, Australia: Trade and Society, 1788-1850 (Sydney: Historic Houses Trust of NSW, 2003); Inglis, 45-64; Joyce Westrip and Peggy Holroyde, Colonial Cousins: A Surprising History of Connections Between India and Australia (Adelaide: Wakefield Press, 2010).

51. Kingston, 36-48; Inglis, 45-64.

52. Dane Kennedy, The Magic Mountains: Hill Stations and the British Raj (Los Angeles: University of California Press, 1996); Phillip D. Curtin, Death by Migration: Europe's Encounter with the Tropical World in the Nineteenth Century (Cambridge: Cambridge University Press, 1989).

53. Queeny Pradhan, "Empire in the Hills: The Making of Hill Stations in Colonial India," Studies in History 23 (2007): 34-55.

54. Judith T. Kenny, "Climate, Race, and Imperial Authority: The Symbolic Landscape of the British Hill Station in India," Annals of the Association of American Geographers 85, no. 4 (1995): 699, 702.

55. Charles Dilke, Travellers' Tales of Early Australia \& New Zealand: Greater Britain, Charles Dilke Visits her New Lands, 1866 \& 1867, edited by Geoffrey Blainey (Sydney: Methuen Haynes, 1985 [1868]), 182.

56. Arnold, Tropics and the Travelling Gaze; Nigel Leask, British Romantic Writers and the East, Anxieties of Empire (Cambridge: Cambridge University Press, 1992); Alan Bewell, Romanticism and Colonial Disease (Baltimore: Johns Hopkins University Press, 1997).

57. Mrs. Muter, Travels and Adventures of An Officer's Wife in India, China, and New Zealand, Vol. 1 (London: Hurst and Blackett, 1864), 125-6.

58. Ibid., 134.

59. On the physical appearance of hill stations, see: Beattie, Empire and Environmental Anxiety. On gender and sports in India, note: Mary A. Procida, "Good Sports and Right Sorts: Guns, Gender, and Imperialism in British India," Journal of British Studies, 40, no. 4 (2001): 454-88; John M. MacKenzie, The Empire of Nature: 
Hunting, Conservation and British Imperialism (Manchester: Manchester University Press, 1988).

60. Jayeeta Sharma, "British Science, Chinese Skill and Assam Tea: Making Empire's Garden," Indian Economic \& Social History Review 43, no. 4 (2006): 429-55.

61. Singh, "Clouds of Cholera'," 144-65; Catanach, "Plague and the Tensions of Empire," 149-71.

62. "Malaria and the value of the Eucalyptus," Indian Forester 7, no. 4 (1882): 336.

63. Michael R. Dove, "'Jungle' in Nature and Culture," in Social Ecology, edited

by Ramachandra Guha (Delhi: Oxford University Press, 1998), 90-115.

64. Richard Harry Drayton, Nature's Government: Science, Imperial Britain, and the 'Improvement' of the World (New Haven: Yale University Press, 2000).

65. Ray Desmond, The European Discovery of the Indian Flora (Oxford: Oxford University Press, 1992), 258-85.

66. Ashley Hay, Gum: The Story of Eucalyptus and Their Champions (Sydney:

Duffy \& Snellgrove, 2002); Tyrrell, 69-70; Beattie, "Colonial Geographies of Settlement," 583-610.

67. On which see: Richard H. Grove, "Conserving Eden: The (European) East India Companies and their Environmental Policies on St. Helena, Mauritius, and in Western India, from 1660 to 1854," Comparative Studies in Society and History 35, no. 2 (1993): 318-51.

68. Bennett, "The El Dorado"; Robin W. Doughty, The Eucalyptus: A Natural and Commercial History of the Gum Tree (Baltimore: Johns Hopkins University Press, 2000), 128-129.

69. E. Morton, "Arboriculture in its relation to Climate," Indian Forester 1, no. 2 (1875): 151.

70. For an entertaining chapter on the Baron, see: Hay, Gum, 71-103. On its anti-malarial properties note especially: Hay, Gum, 88-90; and Kenneth Thompson, "Trees as a Theme in Medical Geography and Public Health," Bulletin of the New York Academy of Medicine, 54, no. 3 (1975): 518-23.

71. J. L. Laird, "The Eucalyptus Globulus: From a Botanical, Economical and Medical Point of View, translated from the French by J. E. Planchon, Professeur à la Faculté de Montpellier," Indian Forester 1, no. 2 (1875): 175-7.

72. J. E. O'Connor, “The Cultivation of 'Eucalyptus Globulus' and other Australian Gums in India," Indian Forester 2, no. 2 (1876): 120-35.

73. Note, for instance: "South Australian Eucalyptus," Indian Forester 3, no. 4 (1878): 317-9; Laird, 156-79; "Decay of Eucalyptus at Changa Manga," Indian Forester 7, no. 1 (1881): 98-100; “Mueller's Eucalyptographia," Indian Forester 11, no. 5 (1885): 237; “The Timber Trees of New South Wales," Indian Forester 11, no. 6 (1885): 272-8.

74. Dr. J. Maitland cited in "Plantation of Australian Trees, Nilgiri Hills," in Hugh Cleghorn, The Forests and Gardens of South India (London: W. H. Allen \& Co., 1861), 180-1.

75. Cleghorn, 339; G. Foster, "Plantation of Eucalypti," Indian Forester 2, no. 3 (1877): 324.

76. Robin W. Doughty, The Eucalyptus: A Natural and Commercial History of the Gum Tree (Baltimore: Johns Hopkins University Press, 2000), 129.

77. Cleghorn, 339; for complaints at the 'heavy charges' incurred from importing Australian seeds, see: O’Connor, 131.

78. Laird, for instance, recounted examples of successful drainage and health improvements in Algeria and southern France: Laird, 166-8.

79. Cleghorn, 42-3, 171-91.

80. D. Brandis to Editor Ootacamund, 7 April 1882, "The Forests of South India," Indian Forester 7, no. 4 (1882): 366.

81. D. Brandis, "On the Distribution of Forests in India," Indian Forester 9, no. 5 (1883): 224; O’Connor, 120.

82. Hugh Cleghorn, "Third Report on Forest Operations," 31 August 1860, in 


\section{JAMES BEATTIE}

Cleghorn, Forests, 82

83. O'Connor, 128

84. O'Connor, 124

85. Brett M. Bennett, "A Global History of Australian Trees," Journal of the History of Biology 44 (2011): 125-45.

86. Warwick Anderson, The Cultivation of Whiteness: Science, Health and Racial Destiny in Australia (Melbourne: Melbourne University Press, 2002), 20, 35-8.

87. Mrs. Charles Meredith, Notes and Sketches of New South Wales, During A Residence in that Colony from 1839 to 1844 (London: John Murray, 1844), 85.

88. Sir John Cracroft Wilson, "Transcript of Diary/Recollections, 1854, of Canterbury," typed transcript by Ron Chapman, 1989, Archives New Zealand, Christchurch Regional Office, ARC1989.80, 6.

89. William Howitt, Land, Labour and God; or Two Years in Victoria (London: Longmans, 1855), quoted in Anderson, Cultivation, 127.

90. Inglis.

91. Rolf Boldrewood, Old Melbourne Memories (1884) quoted in Paul Fox, "The Simla of the South," The Changing Landscape: The Garden in the Landscape: Proceedings of the Australian Garden History Fifteenth Annual National Conference, 21-23 October 1994 (Ballarat: Australian Garden History Society, 1994), 10, 11.

92. Fox, 11.

93. Resulting from 'cultures in contact,' notes historian Anthony King, the bungalow was 'an indigenous mode of shelter adopted and adapted for Europeans living in India.' The native word 'bangla' was adapted to 'bungalow.' The dwelling was enlarged, different arrangements of space, and new construction materials used, while aspects of its form were introduced elsewhere in the world, all with local variation. Anthony D. King, The Bungalow: The Production of a Global Culture (London: Routledge and Kegan Paul, 1984), 14-64.

94. Alfred Deakin, "Diary, Indian 1890-91," Deakin Papers, National Library of Australia, quoted in Fox, 13.

95. Inglis, 84-85.

96. Carlton and Carlton, 50. 